\title{
REFLEXÕES SOBRE MORALIDADE E DIREITO ADMINISTRATIVO
}

\author{
Juarez Freitas
}

\section{RESUMO}

O princípio constitucional da moralidade sugere um novo e profundo controle dos atos administrativos, e permite uma assimilação efetiva do direito fundamental para a boa administração pública. Moralização é um risco a ser afastado, por exemplo, a hipertrofia deste princípio em detrimento de outros. Assim, neste artigo, uma adequada, moderada e proporcional aproximação será abordada.

Palavras-chave: Administração pública. Atos administrativos. Moralidade. Princípio constitucional.

\section{INTRODUÇÃO}

Moralidade é, em nosso sistema, princípio jurídico e, como tal vinculante. Nessa perspectiva, o Direito Administrativo, mormente com o advento da Carta de 1988, começou a ser relido à luz do caráter vinculante do princípio constitucional da probidade, inerência do direito fundamental-síntese à boa administração pública ${ }^{1}$. Mas força reconhecer que segue indispensável enfatizar (numa abordagem moderada e proporcional) que o princípio constitucional da moralidade, entendido como prescrição jurídica de conduta eticamente universalizável de modo satisfatório, não deve ser confundido jamais com moralismo não-universalizável, por definição. Mais: a boa defesa do princípio da probidade pressupõe o afastamento de qualquer tentação monista que pretenda identificar plenamente as esferas do legal e do moral. Bem por isso, no presente artigo, o tema será desenvolvido à base das seguintes premissas:

(a) Os princípios fundamentais (entre os quais o da moralidade) encontram-se mutuamente relacionados, todavia guardam especificidades: não é correto asseverar que a violação de um princípio implique a infração automática dos demais. Os princípios e direitos fundamentais, por assim dizer, tocam-se, porém há condições para que sejam imediata e nuclearmente tidos como violados, quais sejam: (i) a violação deve ser grave a ponto de atingir o seu âmago e (ii) o princípio precisa ser alvejado, não remota ou mediatamente, mas em seu círculo eficacial próprio. Dito de outro modo, como o Direito é, sem controvérsia, mais do que a lei, disso decorre que o Direito Administrativo deve ser assimilado como mais do que a lei de probidade. É o mútuo relacionamento dos princípios e direitos fundamentais justifica, em larga medida, a aludida vinculação entre Direito e Moral: nesse sentido, o constituinte acolheu a melhor postura, ao incorporar o princípio da moralidade, contudo 
sem intentar o absurdo monismo pleno (equívoco que representaria a negação dos demais princípios).

(b) Ao mesmo tempo, não se acolhe a mera positivação da moralidade: realiza-se autêntica proclamação da eficácia direta e imediata desse princípio como inerência do direito fundamental à boa administração pública, de modo que a probidade tem que ser considerada em toda e qualquer hierarquização tópico-sistemática, na toma de decisões administrativas, vale dizer, em toda justificação eficiente, eficaz e moralmente universalizável.

(c) Além disso, o princípio da moralidade é visto, sob certo aspecto, como pedra de arrimo do Estado Democrático, no âmbito das relações jurídicas em geral, guardadas as diferenças funcionais entre as esferas do público e do privado. Útil lembrar Norberto Bobbio:2 "a democracia é o sistema político que nos permite a maior aproximação possível entre as exigências da moral e as da política." Logo, o agir eticamente universalizável desponta como uma imposição válida para todas as relações jurídicas (no tocante aos deveres de transparência e de informação fidedigna, isto é, sem ardis, enganos intencionais ou má-fé). Tudo de molde a requerer, na sociedade democrática, a superação da postura infecunda que entendia o Direito e a Moralidade como inconciliáveis conceitualmente. Cogite-se, por exemplo, de Joseph Raz ${ }^{3}$, ao sustentar que o conteúdo do Direito poderia ser determinado sem qualquer referência a argumentos morais. ${ }^{4}$ Ora bem, a explicitação insofismável da natureza axiológica da Constituição é dado definitivo, nessa altura, em face da inserção vinculante do princípio constitucional da moralidade. Afasta-se, com isso, vasta gama de erronias, notadamente associadas ao hard positivism, já que se assume não ter havido apenas a nominal incorporação de diretriz vaga, mas o reconhecimento de indescartável critério constitucional de condutas.

Nesse enfoque, a questão medular reside em saber os limites, na prática, da vinculação entre Direito Administrativo e Moralidade, evitando embaralhar as esferas, assim como sucumbir a emocionalismos perigosos e, não raro, imorais, ou seja, não-universalizáveis de modo satisfatório (para evocar Kant, desvestido de seu formalismo). Dito de outro modo, sobrepassados ceticismos excessivos ou pragmatismos radicais ${ }^{5}$, a passagem do ser para o dever-ser precisa ser racionalmente controlável. No ponto, Jürgen Habermas bem propõe que a legalidade extraia a sua legitimidade de uma racionalidade procedimental com teor moral ${ }^{6}$. Não há espaço, no presente artigo, para apontar vantagens e insuficiências das teorias procedimentalistas. ${ }^{7}$ Para os fins do presente estudo, suficiente assimilar que as argumentações morais restaram cogentes no sistema administrativista, fenômeno que sobe de ponto a partir da incorporação do princípio da moralidade, de modo expresso na Constituição, nos arts. $5^{\circ}$ e $37 .{ }^{8}$ Quer dizer: ao menos no modelo constitucional brasileiro, não se afigura plausível asseverar que o EstadoAdministração deve apenas agir em estrita conformidade com regras legais, a despeito do peso residual do légicentrisme. A avaliação e o controle ${ }^{9}$ dos atos administrativos deve, por isso, acontecer de modo a aferir a moral congruência da conduta com o Direito, tarefa extremamente mais complexa e importante do que aquela que se cingia a impor (geralmente, sem êxito) o respeito acrítico às regras de conduta. 
Então, em sincronia com as premissas eleitas, na seara propriamente das relações publicistas, vê-se que a ação ímproba do agente público, ainda quando não cause qualquer dano material ao erário, nem enriquecimento ilícito, pode já representar uma violação nuclear e inescusável do princípio da moralidade, de maneira a configurar improbidade administrativa, nos termos do art. 11 da Lei 8.429/92, isto é, a chamada improbidade por violação a princípios, desde que presente inequívoca intenção desonesta à luz do senso médio superior da moralidade vigente. Como se nota, ampliou-se o espectro do dever de probidade do agente público, que precisa até rejeitar ordem superior manifestamente imoral, pois a legalidade passa a ser vista como princípio relativizado (embora não absorvido) pela moralidade.

De conseguinte, indefensável hipostasiar o princípio da legalidade-regra. Argumentar com o só cumprimento de ordens não se mostra convincente, sempre que tais ordens forem flagrantemente imorais. Em outro dizer, o Direito não é mais visto, nas teorias de ponta, como simples conjunto enclausurado e claustrofóbico de regras, nem estas merecem ser tidas como os mais nobres componentes do sistema. É que a inclusão de preocupações com a moralidade (com a devida justificação racional) no âmbito do controle sistemático de juridicidade, longe de destruir o sistema jurídico, constitui condição sine qua non para a afirmação democrática do Estado-Administrador, nos trilhos da honradez republicana.

\section{O PRINCÍPIO CONSTITUCIONAL DA PROBIDADE: DESAFIOS HERMENÊUTICOS}

Almeja-se viabilizar o processo de governança pública proba, no tocante a meios e fins moralmente aceitáveis, na ciência de que responsabilidade e princípios são eticamente conciliáveis. Claro que, ao se negar a neutralidade axiológica, não se abre mão do propósito da imparcialidade, ${ }^{10}$ mas se reconhecem as demandas inafastáveis de legitimação ético-jurídica das decisões administrativas. Vale dizer, sem cair em falácias formalistas, no exame da legitimidade da produção dos atos administrativos, útil sublinhar que se faz imprescindível avaliar, para além do quantificável ${ }^{11}$, as condutas administrativas naquele espaço que transcende a "completude" preconizada pela escola da exegese ou, mais sofisticadamente, pela teoria da norma geral exclusiva $^{12}$, exercitando, asim, a "porosidade" do jurídico na seara de apreciações marcadamente morais, que expandem a noção de juridicidade.

Decerto, impõe-se lamentar que ainda se ouça, aqui e acolá, o argumento frágil de que algo pode ser, ao mesmo tempo, lícito e desonesto, na gestão pública, na tentativa vã de expulsar as considerações sobre a moralidade da esfera do controle. Contudo, a restauração da credibilidade e da legitimidade ética do Estado-Administração não pode ser alcançada por abordagens formalistas ou reducionistas. Em outras palavras, embora sem aderir a ativismos extremados e hostis à fundamentação racional, impende destacar que a decisão administrativa requer, na escolha das premissas, a valorização do pape $^{13}$ do princípio da probidade. Sim, a explicitação dos fundamentos dos atos administrativos que afetarem terceiros, nos termos dos 
art. 50 da Lei 9.784/99, precisa incluir, sob pena de nulidade, considerações de natureza axiológica. A simples e rústica invocação dos artigos de lei, como visto, é de nulidade escancarada. Por igual, a retórica invocação de oportunidade ou conveniência, dissociada de elementos comprobatórios, é acinte contra a racionalidade dialógica e contra a "lei moral" ${ }^{14}$, que devem ser a tônica do Direito Administrativo no século em curso. Trata-se, pois, de nova e incontornável postura, no exame da motivação dos atos administrativos, que não se confunde com moralismo arbitrário, tampouco endosssa qualquer desproporcionalidade.

Portanto, o controle sistemático dos atos administrativos há de se deixar guiar, sempre e sempre, em função do primado dos direitos e princípios fundamentais ${ }^{15}$, para além das regras, já que o dever primeiro é o de velar pelo sistema hierarquizável de princípios (superiores, axiologicamente), tendo as regras o papel de, prestimosamente, servir à densificação dos princípios, nunca de mutilá-los. O controle sistemático, guiado pelas diretrizes principiológicas superiores, é o que se mostra em condições de conferir a devida concatenação interna ao ordenamento, impossível de obter pela simples consideração inarticulada das regras. Com efeito, ao contemplar os preceitos jurídicos, a tarefa suprema reside em bem hierarquizar princípios, regras e valores, emprestando a maior efetividade possível ao conjunto orgânico que daí exsurge, a um só tempo, aberto e unitário. Controlar - assim como interpretar os conteúdos jurídicos - é hierarquizar deontológica e axiologicamente, de modo tópico-sistemático. Nessa trilha, mister assumir que, nas fronteiras do sistema objetivo, jamais se deve aceitar o exame insular dos deveres, dado que o controle sistemático solicita a junção ético-jurídica dos aspectos constitutivos do Direito Administrativo. Deve o controlador, assim, salvaguardar a eficácia axiológica do sistema, certo de que, quanto mais complexo este se revelar, tanto mais carecerá de efetivação a tutela inibitória da imoralidade administrativa por ação ou omissão.

Nessa ordem de considerações, do princípio da moralidade descende, diretamente, o também expressamente agasalhado princípio da probidade administrativa. Pois bem: é justamente o princípio da probidade que se pretende, doravante, confrontar com as regras vigentes, notadamente as trazidas pela Lei $8.429 / 92$, sobremodo para realçar a necessidade de nova atitude hermenêutica que se revele mais firme e disposta a conferir crescente força vinculativa à moralidade como princípio jurídico, uma vez que o destino das regras somente pode ser o de contribuir à concretude das diretrizes maiores.

Deveras, semelhante posição hermenêutica precisa proteger, por inteiro, a leitura guiada pela Lei Fundamental e contribuir para a mais improtelável e fulcral das mudanças no plano das relações administrativas, as quais devem ser reorientadas pela efetividade (mensurável, sempre que posssível) dos princípios e direitos fundamentais, consideradas as transformações necessárias do Direito Administrativo, rumo ao desenvolvimento humano que importa. O objetivo das relações de administração nada mais há de ser do que a realização otimizada dos princípios constitucionais, de sorte a permitir que o vínculo jurídico se aperfeiçoe pelo amplexo das volições parciais com a vontade, por assim dizer, pública. Dessa maneira, a relação publicista reclama 
ser aperfeiçoada com o objetivo de estimular o mais pronto e profundo reconhecimento de elevados patamares éticos, que não sufoquem o que há de mais digno no indivíduo, tampouco cedam ao individualismo niilista. Tudo para erguer o Estado-Administração, no qual a vontade geral não seja o fruto da sórdida abstração similar àquela dos que se resignam a nomenclaturas repletas de vilipêndios contra as reivindicações basilares da moralidade pública e universalizável.

$\mathrm{Na}$ senda, assim, de tornar factível a concretização do princípio da probidade administrativa, por meio da inteligência comedida do diploma em apreço (Lei 8.429/92), antecipam-se asserções dimanantes da compreensão sistemática do tema. Ei-las, em largos traços, sem pretensão de exaustividade:

a) na avaliação da improbidade, o controle (especialmente o judicial) deve considerar, com extrema cautela, a "extensão do dano" e o "proveito patrimonial do agente", motivo pelo qual, em especiais circunstâncias, pode e precisa determinar a aplicação apenas parcial das penalidades retributivas, desde que tal postura brote do intuito fundamentado de robustecer o princípio da moralidade, cuja concreção moderada há de ser tida como o desiderato normativo maior;

b) com igual firmeza, comprovando-se a improbidade administrativa ensejadora de enriquecimento ilícito, por sua nota de irretorquível e gravíssima hostilidade ao princípio do interesse público, deve o controlador aplicar, na íntegra, as sanções cabíveis, ao menos no geral das vezes;

c) nada obstante a dicção literal, considera-se facultativo o litisconsórcio da pessoa jurídica prejudicada, tendo em vista a partícula disjuntiva a ser adiante enfocada, da mesma sorte que, para além da literalidade, resulta inegável cuidar-se de arresto, não de seqüestro, a figura introduzida pelo diploma em apreço, impondo-se, pois, os devidos cuidados no processamento;

d) as cominações relativas às múltiplas espécies de improbidade administrativa não se devem aplicar aos agentes que tenham condutas escusáveis, exatamente em função de não se configurar, aqui, a improbidade, sequer por violação aos princípios fundamentais, cumprindo grifar que a preservação do sistema não se coaduna com desproporcionalidades supostamente moralistas;

e) em rigor, aconselha-se não cogitar da inversão do ônus da prova, na compreensão sistemática da Lei de Improbidade, ao tratar do enquadramento do agente nos tipos nela descritos, uma vez que só existe responsabilidade subjetiva do agente público, numa adequada intelecção do art. 37 , par. $6^{\circ}$ da $\mathrm{CF}$;

f) a figura do dano moral, quando envolve elementos transubjetivos, demandaria ter os seus contornos melhor definidos, inclusive nas hipóteses de improbidade por violação aos princípios. Ao menos por enquanto, porém, afigura-se desnecessário fazê-lo: embora até cogitável, sem absurdo, que pessoas jurídicas de direito público ou de direito privado integrantes da Administração Pública pudessem ser vítimas de dano moral (já reconhecido, 
pacificamente, contra pessoa jurídica de direito privado), o respaldo da acolhida constitucional do princípio da improbidade é motivo suficiente para punir a violação ao princípio em si (independentemente de enriquecimento ilícito ou dano ao erário), sem ter de enveredar para a labiríntica questão;

g) a regra de que a perda da função pública, por improbidade, sucede com o trânsito em julgado da sentença condenatória, não exclui a possibilidade de tal perda resultar do adequado processo administrativo, exceto em relação aos vitalícios;

h) sugere-se que a multa civil, potencialmente de elevada monta, sirva como reparação à quebra do princípio em si, mormente nos casos envolvendo a terceira espécie de improbidade;

i) são dois os requisitos principais para que se verifique a improbidade administrativa (em qualquer das espécies): i-1) grave violação ao senso médio superior da moralidade pública e i-2) inequívoca intenção desonesta. Não basta a ilegalidade, sob pena de moralismo não-universalizável e, portanto, imoral.

Tais e outras soluções hermenêuticas, lançadas para resolver os remanescentes embaraços da legislação, com pronunciados reflexos doutrinários e empíricos, fazem, de imediato, recomendável ressaltar o papel harmonizador da interpretação tópico-sistemática, especialmente quando se pretendem cominar sanções justas e ponderadas, diversas das penalizações ortodoxas (raras vezes, aplicadas contra os grandes infratores).

Acresce que, tratando-se de evitar ou de coibir a agressão contra a moralidade pública (entenda-se bem: em última instância, contra a sociedade civil e contra o Estado Democrático), impõe-se, por todos os motivos, fazê-lo de modo ética e juridicamente irretocável, sempre sem olvidar que a má-fé jamais se presume e que não se deve considerar o agente público objetivamente responsável. ${ }^{16} \mathrm{O}$ elemento volitivo ou subjetivo, nesse passo, mostra-se ineliminável. Dito isso, enfrentar-se-ão os temas mais relevantes a respeito da ação civil de improbidade administrativa, cujo advento brotou de determinação frontal do art. 37, § 40, da Constituição.

Pois bem, associado ao juridicamente autônomo princípio da moralidade administrativa - mais especificação do que qualificação subsidiária daquele -, o princípio da probidade administrativa ${ }^{17}$ consiste na proibição de atos inequivocamente desonestos ou desleais para com o Poder Público, praticados por agentes públicos ou terceiros, concretizado por tipificações e mecanismos sancionatórios inscritos na Lei 8.429/92, que exigem aplicação cercada de cautelas, no resguardo dos limites do próprio princípio.

Como enfatizado, dada a dimensão jurídica do princípio da moralidade, mesmo quando não se verificar o enriquecimento ilícito ou o dano material, ainda assim poderá ocorrer a ofensa ao princípio da probidade, pois o constituinte intentou coibir qualquer grave lesão à moral positivada, inclusive nos casos em que não se constatam, incontroversos, os danos materiais. No entanto, a adequada e percuciente intelecção, em especial do diploma em 
apreço, conduz a que não se apliquem as pesadas sanções ali cominadas no caso de infrações leves ou perdoáveis, exatamente por não se configurar, a rigor, improbidade. O que o sistema tenciona é inibir a quebra nefasta do princípio, seja pelo agente público ou por terceiro, punindo, aí sim, com a imposição de penalidades assaz severas, incompatíveis com as infrações de menor lesividade. Reitere-se, porém, que nada impede que a grave afronta seja perpetrada pela via oblíqua, isto é, pela violação aos demais princípios regentes da Administração Pública, desde que a moralidade seja inequivocamente atingida, de modo simultâneo. Assim, exige-se, para que a conduta (omissiva ou comissiva) seja catalogável como a de um ímprobo, que se caracterize o destoamento nítido da moralidade, segundo o senso médio superior, a par da presença clara de intenção desonesta. Não basta o engano ou a irregularidade por ignorância. Em contrapartida, para citar exemplo emblemático, após (e somente após) a edição de Súmula Vinculante do STF protetora simultânea da impessoalidade e da moralidade - já não fará mais sentido alegar ignorância do dever moral de coibir o nepotismo, segundo orientação cristalizada pela Corte Constitucional.

Certo, assim, que o princípio da probidade administrativa veda a violação de qualquer um dos princípios, independentemente da caracterização do dano material, desde que tal violação se revele causadora concomitante da lesão à moralidade administrativa, prejuízo este a ser aferido por critérios que não devem descansar as suas raízes em juízos ordenados pela vindita ou pela descontextualização histórica, recomendando-se temperança aos controladores, sem entrega a subjetivismos contingentes, ainda que nutridos de ótimas intenções.

Mais: pratica improbidade administrativa qualquer agente público, consoante a dicção elástica do art. $2^{\circ}$ da Lei 8.429/92, (servidor ou não, inclusive - a despeito de controvérsia jurisprudencial - o agente político ${ }^{18}$, 0 contratado por tempo determinado, temporário e celetista) que atentar contra as pautas morais da Administração Pública, assim como de empresa incorporada ao patrimônio público e de entidade para cuja criação ou custeio o erário haja concorrido ou concorra com qualquer valor. ${ }^{19}$ Com efeito, em linha analógica com o raciocínio que indica inaceitável, em sede de ação popular, acolher as restrições colimadas pelo art. $1^{\circ}$ da Lei $4.717 / 65$, por não recepcionadas pela Constituição, imperativo sustentar que, no manejo de recursos públicos, sempre se poderá verificar a improbidade administrativa, sem embargo de render ensejo, noutro contexto processual, à anulação do ato lesivo. De mais a mais, já se encontram sujeitos às sanções da Lei de Improbidade os atos praticados contra o patrimônio de entidades que recebam subvenção, benefício ou incentivo, fiscal ou creditício, de órgão público e daquelas para cuja criação o erário haja participado com menos da metade do patrimônio ou da receita anual, limitando-se, nestas situações, a sanção patrimonial à repercussão do ilícito sobre a contribuição dada pelo Poder Público (art. $1^{\circ}$, parágrafo único). Ora, a "extensão do dano" invariavelmente deve ser levada em consideração, não apenas ao fixar, senão que ao escolher penalidades. Sem maior sentido, de conseguinte, a distinção supostamente pretendida no parágrafo único de dispositivo ${ }^{20}$.

Mais: a Lei Maior exige que se interpretem os comandos em tela em 
harmonia com a abrangência dada pelo art. 70, parágrafo único, que determina a prestação de contas de qualquer pessoa física ou entidade pública que utilize, arrecade, guarde, gerencie ou administre dinheiros, bens e valores públicos ou pelos quais o Poder Público responda ou que, em nome deste, assuma obrigações pecuniárias. Urge, pois, para conferir a máxima força vinculante ao princípio, abarcar, no conceito de agente público, a pessoa física aí descrita, desde que, está claro, tenha entretecido qualquer vínculo jurídico, ainda que tênue, com a Administração. No entanto, se isso não for aceito, enquadrar-se-á a hipótese, de qualquer modo, no art. $3^{\circ}$, relativo a outros que não os agentes públicos, indutores ou concorrentes para os indigitados atos ou deles beneficiários.

Bem observadas as coisas, não devem ser inseridos no rol dos que atentam contra o princípio da probidade aqueles que, v.g., cometem o delito (altamente censurável) do tráfico de influência (já tipificado, penalmente, pela Lei $9.127 / 95)$, se insinuaram ou alegaram que a vantagem seria também destinada ao servidor, sem induzir propriamente a prática do ato censurável pelo agente público. Entretanto, se se tratar de agente público o autor do pedido da vantagem, mesmo que esta não se consume, cristalizar-se-á, sem dúvida, infração à Lei de Improbidade, sem prejuízo das sanções penais.

Reitere-se uma vez mais: até aqueles que não se enquadraram no conceito latíssimo de agente público, podem ainda receber o influxo do comando endereçado a terceiros que induzam ou colaborem para a prática da improbidade. Em semelhantes moldes, a intelecção proposta robustece, de maneira sensível, a possibilidade de punir com a suspensão dos direitos políticos, a par da cominação civil, os que - acima de dilema - cometam atos ou omissões indisputavelmente reprováveis em face da moralidade pública.

Frise-se que a improbidade administrativa é uma das hipóteses constitucionais de suspensão dos direitos políticos, ao lado do cancelamento da naturalização por sentença transitada em julgado, incapacidade civil absoluta, condenação criminal definitiva e recusa de cumprir obrigação imposta a todos ou prestação alternativa. Em qualquer caso, a suspensão do gozo de direitos políticos é medida de extraordinária severidade, que implica, entre outros efeitos, ao lado da inelegibilidade e do cerceamento do direito de voto, a proibição de se filiar a partido político e a vedação de investidura em cargo público, além da falta de legitimidade para intentar a ação constitucional popular. Quanto a este último efeito, assinale-se que a legislação de regência mereceria ser revista, pois o instituto da cidadania, à evidência, não se exaure no gozo dos direitos políticos.

Especificamente para reprimir o cometimento da improbidade administrativa, a Lei Maior estabelece, em traços não-taxativos - remetendo à forma e à gradação estabelecidas na legislação ordinária, e sem prejuízo da ação penal -, aquelas que devem ser as principais sanções, quais sejam, a suspensão da fruição dos direitos políticos, a perda da função pública, a indisponibilidade dos bens e o imprescritível ressarcimento ao erário (CF, art. 37, §§ 4으 e 5의), ao menos em relação aos danos causados pela improbidade.

Vai daí que a ação de improbidade administrativa enquadra-se no rol 
das ações civis constitucionais. Deve ser tida como singularíssima e independente das esferas penal e administrativa, inclusive desconsiderando a aparente exceção em relação à última, que será oportunamente comentada, tendo em vista o disposto no art. 20 da Lei da Improbidade, o qual, se não se vencesse o textualismo exacerbado, tenderia a burlar a independência de instâncias. ${ }^{21} \quad$ No que concerne à independência em relação à ação penal verifica-se, em parte, pela própria dicção do art. 37, § 40, da CF, quando menciona que os atos de improbidade administrativa importam a suspensão dos direitos políticos, a perda da função pública, a indisponibilidade dos bens e o ressarcimento ao erário, na forma e gradação previstas em lei, "sem prejuízo da ação penal cabível”.

Esclarecido esse ponto, urge consignar que, no atual modelo normativo, múltiplas são as espécies de improbidade administrativa, conquanto separadas, às vezes, por brandas linhas demarcatórias. Observe-se que nem todos os atos ímprobos apresentar-se-ão necessariamente classificáveis na rubrica de atos administrativos em sentido estrito, fazendo-se imprescindível, em qualquer caso, que se configurem as condutas ou práticas negadoras da probidade administrativa.

A primeira modalidade concerne aos atos de improbidade administrativa que acarretam enriquecimento ilícito por ter o sujeito auferido qualquer tipo de vantagem indevida em razão do exercício de cargo, mandato, função ou emprego, ou atividade pública, no sentido amplo (art. $9^{\circ}$ ). Com o fito elucidativo e para figurar situação dessa primeira - gravíssima - modalidade, convém mencionar o ato de aceitar emprego, comissão ou exercer atividade de consultoria para pessoa física ou jurídica que tenha interesse suscetível de ser atingido ou amparado por ação ou omissão decorrente das atribuições do agente público. Naturalmente, deve-se verificar, na espécie, apesar da imperfeita redação da norma, o nexo de prejuízo à Administração e o conseqüente enriquecimento ilícito, pois mesmo que resulte, sem o menor sofisma, proibida a mencionada aceitação, o descumprimento dessa vedação não se apresenta capaz, por si só, de implicar a improbidade dessa primeira espécie.

Exame que merece detença adicional é o do ato de improbidade por enriquecimento ilícito, que consiste em adquirir, para si ou para outrem, bens de qualquer natureza cujo valor seja desproporcional à evolução do patrimônio ou à renda do agente. Com a devida prudência, não se deve admitir inversão do ônus da prova - embora esta quase tenha figurado na formatação final do texto normativo -, mas a mera consideração de que se mostra robusto, não suficiente, o indício da ausência de origem para tornar ilícita a renda assim obtida, sobretudo tendo em conta a transparência advinda do regime publicista de trabalho daqueles que lidam com a coisa pública. É preciso, porém, provar o nexo entre o referido enriquecimento e a atuação pública. A rigor, não se deve jamais identificar, na situação aludida, a inversão do ônus da prova, uma vez que não se pode esgrimir com uma abstrusa e inconstitucional responsabilidade objetiva do agente público. Não há, em nosso sistema, plausibilidade para a tese da responsabilidade do agente público que dispense a investigação subjetiva (dolo ou culpa), por força do art. 37 , par. $6^{\circ}$ da CF. 
Incontestavelmente, em suma, aquele que intentar a ação terá que se basear, v.g., na declaração de bens e, por acréscimo inevitável, no induvidoso nexo causal do enriquecimento ilícito com a atuação pública. Descabe a alegação temerária, sem solidez ou pelo só gosto de testilha, com base em incertos sinais exteriores de riqueza. Sublinhe-se que não se admite a culpa presumida, já que a formação da prova carece de esforço consistente, mais do que de frágeis ilações.

Não por acaso, em boa hora, legislação superveniente corroborou a obrigatoriedade da declaração de bens e rendas para o exercício de cargos, empregos e funções públicas, sendo que a Lei da Improbidade cuidou, com amplitude, de estabelecer tal exigência, preceituando que a posse e o exercício do agente ficam condicionados - sob pena de não se permitir aquela ou de ser aplicada a pena demissória - à apresentação da declaração, anualmente atualizada, dos bens e valores que compõem o patrimônio privado, com a meta de, por sério cotejo revestido de objetividade, apurar se ocorreu uma ignominiosa variação patrimonial desenraizada e denunciadora do repudiável enriquecimento ilícito no exercício de atividade pública, lato sensu. Ainda assim, o trabalho de fazer a boa prova do nexo aludido não resultou dispensado.

Pelo articulado, imperioso que o ônus da prova não se perceba tecnicamente como invertido ${ }^{22}$, neste como em todos os casos de improbidade, sequer ao se cuidar dos atos de improbidade que afetam direitos do usuário de serviços públicos. De modo geral, o agente público que, por desonestidade, desrespeitar os direitos do usuário de serviços essenciais violará a probidade administrativa, sendo, nada obstante, inafastável a incumbência do autor de efetuar a prova no tocante à prática omissiva ou comissiva do agente, porque a responsabilidade extracontratual objetiva aplica-se apenas às pessoas jurídicas de direito público ou de direito privado prestadoras de serviço público. Leitura diversa, como visto, ensejaria resultado maculado por inconstitucionalidade, ao introduzir figura de responsabilidade não admitida na Constituição. A par disso, tampouco se mostra aplicável o comando do art. 334 do CPC, consoante o qual não dependem de prova os fatos notórios ou em cujo favor militaria uma presunção legal de existência ou veracidade, dado que não se enquadra em nenhuma das situações ali enfocadas.

Sempre em consórcio com o princípio da proporcionalidade ${ }^{23}$, bem de ver que as sanções não reclamam, em todos os casos, uma aplicação conjunta, até para que se alcance a sensatez pretendida, de maneira a escoimar do texto legal qualquer vezo draconiano que conspire contra a sua própria efetivação. Contudo, para não desprestigiar o sistema, defrontado o controlador judicial com improbidade cumulada com enriquecimento ilícito - a mais torpe das espécies de improbidade -, à vista da magnitude da violação, deve aplicar as sanções em sua totalidade, ao menos em regra. Diversamente, no atinente às outras espécies de improbidade, antecipa-se que não se trata de cominações que se devam considerar em moldes tão rígidos, destacadamente quando relacionadas a atos de improbidade por violação a princípios. Dito sem titubeio: com a devida motivação, as sanções (previstas no art. 12 da Lei 8.429) podem ser aplicadas isoladamente, na salutar compreensão de que a lógica jurídica não se circunscreve a silogismos formais, nem se destina a soluções 
traduzíveis em extremos, sob pena de, na prática corrente, redundar triunfante a antijuridicidade ou o erro de combater o mal com o mal maior.

Por meio da exegese preconizada, ao se admitir a aplicação singularizada das penalidades, exceto na maior parte dos casos do art. $9^{\circ}$, outorga-se interpretação teleológica e proporcional à dicção do parágrafo único do art. 12, ou seja, sem retributivismo destituído do senso de eqüidade. É dizer, na mediação fixadora das penas políticas e civis, o juiz levará em conta a extensão do dano, assim como o proveito patrimonial logrado pelo agente, não apenas para dosar as penalidades, senão que para elegê-las. Tal atitude resulta a mais favorável às finalidades eticizantes do diploma legal, por meio da contemplação das circunstâncias objetivas e subjetivas, agravantes e atenuantes, da ação ou omissão reprovável, com a cautelosa prerrogativa de, ao apreciar o caso, zelar pela não-instauração do destempero.

Ressalte-se que, no geral das vezes, para a modalidade que acarreta enriquecimento ilícito, as sanções precisam ser aplicadas de modo global, em função da gravidade do ato praticado. Ei-las: a perda dos bens ou valores acrescidos ilicitamente ao patrimônio (mister perceber que não se trata de mero efeito da condenação, como na seara penal), ressarcimento integral do dano, perda da função pública, suspensão dos direitos políticos de oito a dez anos, pagamento de multa civil de até três vezes o valor do acréscimo patrimonial e proibição de contratar com o Poder Público ou receber benefícios, incentivos fiscais ou creditícios, direta ou indiretamente, mesmo que por intermédio de pessoa jurídica da qual seja sócio majoritário, pelo prazo de dez anos.

Observe-se, quanto à proibição de contratar, que tal penalidade poderia, à primeira impressão, transcender àquela imposta pela declaração de inidoneidade, contida na Lei de Licitações (art. 87, IV). Todavia, ali se diz "enquanto perdurarem os motivos" determinantes. Ao mesmo tempo, impende observar que não se descortina dificuldade maior para aplicar as sanções contidas na Lei 8.429 (no que couber, é claro) à pessoa jurídica. À evidência, não se cuida, aqui, de aplicar a teoria da desconsideração da personalidade jurídica. Cristaliza-se não propriamente uma transposição sancionatória (vedada, aliás), mas a simples sanção de pessoa que ofereceu o seu aporte ao aperfeiçoamento do ato ímprobo.

A segunda espécie é a relativa aos atos de improbidade que resultam prejudiciais ao erário, vale dizer, quando o agente, por ação ou omissão, dolosa ou culposa, causa perda patrimonial, desvio, malbaratamento por desaviso e negligência ou dilapidação dos bens ou haveres públicos. Deveras, a avaliação do grau de violação há de, outra vez, tomar em consideração a extensão do dano, desconsiderando a infração leve ou levíssima e aquela que não revelar inequívoca desonestidade. Em outras palavras, urge ver preservada a simétrica compatibilidade das eventuais sanções aplicadas com o ato ou omissão em foco, sob pena de desproporcionalidade irremissível, numa afronta manifesta ao princípio da moralidade, vinculado umbilicalmente à idéia de proporção, cujo prestígio, por fortuna, a pouco e pouco, parece crescer em nosso ambiente. ${ }^{24}$

Em relação a tal espécie de improbidade administrativa, as sanções 
prosseguem drásticas, mormente se e quando enfeixadas numa totalidade, conquanto já não tão severas quanto as comináveis para os atos da primeira espécie: além do ressarcimento integral do dano (incluindo a reparação pela quebra do princípio), sujeita-se o agente ímprobo lesivo ao erário à perda da função pública, à suspensão dos direitos políticos de cinco a oito anos, ao pagamento de multa civil de até duas vezes o valor do dano e à proibição de contratar com o Poder Público ou de receber benefícios, incentivos fiscais ou creditícios, diretamente ou por via oblíqua, pelo prazo de cinco anos. Como se observa, por evidente lapso, cogitou tal dispositivo de aplicar a perda dos bens ou valores acrescidos de maneira ilícita ao patrimônio. Fácil notar que, se tal sucedesse, em boa técnica, estar-se-ia, insofismavelmente, perante ato de improbidade da primeira espécie, cumprindo, pois, que o aplicador não se impressione com mais essa confusão redacional patrocinada pelo legislador. Convém gizar que a interpretação jurídica há de ser sistemática, ou não merece o designativo de interpretação.

A terceira espécie de improbidade administrativa causa estranheza tãosomente aos que ainda não desvendaram a estrutura não apenas normativa estrita, mas predominantemente principiológica do sistema administrativo. $\mathrm{Na}$ melhor visada, a infringência de qualquer princípio ou direito fundamental acarreta a violação, em graus diversos, do sistema. Certo que, até para não esfumaçar a identidade do princípio em consideração, importa ter presentes determinados requisitos, até para não ofender 0 princípio da proporcionalidade ${ }^{25}$, para que seja configurada tal espécie de improbidade administrativa, a saber: (a) a grave violação ao senso médio superior de moralidade e (b) a inequívoca intenção desonesta do agente. Não acontece, portanto, à luz das premissas adotadas, essa espécie de transgressão à moralidade na hipótese de violação tênue de outros princípios ou de engano. Por exemplo, não é certo asseverar que a mera participação em licitação de pessoas impedidas seria bastante para fazer incidir a regra do art. 11 da Lei de Improbidade. Ao revés: casos há em que até o dano patrimonial (por óbvio, ilícito) pode ser tido como irrelevante ou de "potencial ofensivo de baixa agressão à moralidade pública", ${ }^{26}$ não sendo de estranhar tal intelecção, pois nem todos os atos censuráveis ou puníveis sê-lo-ão para os efeitos da pesada e rigorosa Lei de Improbidade. É que - sublinhe-se para evitar incompreensão o princípio guarda feições próprias e apenas a violação grave é que pode determinar a aplicação razoável das sanções correspondentes, sob pena de injustiça manifesta.

Claro, tudo repercute em tudo na esfera jurídica, todavia com importantes variações de grau. Desse modo, bem interpretada a espécie em comento (art. 11 da Lei 8.429), a improbidade, aqui, somente se aperfeiçoa pela ofensa simultânea à moralidade e a um ou mais princípios, seja por ação ou por inoperância, transgredidos os deveres de retidão e lealdade ao interesse público e ao Estado Democrático.

Outra vez, em técnica redacional infeliz, dado que o princípio da moralidade ostenta a mencionada identidade, a Lei 8.429 enquadrou nessa espécie de improbidade 0 ato violador da legalidade, confundindo e embaralhando os princípios em tela (art. 11, caput). Nada disso sucede, está claro, se prevalecer a leitura que assume a perspectiva de emprestar a máxima 
eficácia ao princípio constitucional da probidade administrativa, em coerência com o sistema, inteligentemente assimilado. Apesar de a dicção literal do comando não ser das mais louváveis, o acertado é dele inferir que, só quando entretecidos os nexos entre os princípios (moralidade e legalidade, no caso), é que o cometimento da irregularidade, acompanhada da marca indelével da desonestidade do agente ${ }^{27}$ e da deslealdade para com o senso médio superior de moralidade, acarreta a violação do princípio constitucional da probidade administrativa. Não existe, além disso, má-fé objetiva. É equívoco sério supor que o simples erro legal do agente, sem desonestidade ou por engano, deva ser enquadrável como improbidade administrativa. É até imoral fazê-lo. Força que se configure, dada a gravidade das sanções, a irretorquível intenção desonesta do agente público, por exemplo, ao descumprir a regra que veda o nepotismo. Extrapolando: idêntico raciocínio se pode operar em relação aos demais princípios (não apenas o da legalidade), o que dá tom inteligível ao disposto no art. $4^{\circ}$ da Lei de Improbidade, convindo notar que, a não prosperar tal entendimento, o dispositivo resultaria, na melhor das hipóteses, inócuo ou contraditório.

Nesse quadro, a situação inscrita no art. 11, VII, é a que melhor ilustra a violação ao princípio da probidade, nos termos delineados para a espécie. Trata-se de revelar ou permitir que chegue ao conhecimento de terceiro, antes da veiculação oficial, teor de medida política ou econômica. Efetivamente, pode suceder, nesse caso, de não haver o enriquecimento ilícito - ou se tornar inviável in casu a sua prova -, assim como inexistir qualquer dano material ao erário, porém o princípio da impessoalidade restará violado e se afetará gravemente a moralidade. Disso resulta o choque contra o princípio da probidade administrativa. Por imperioso, ratifique-se a idéia-chave de que os princípios sempre irradiam efeitos, embora em intensidades diversas, uns sobre os outros, conquanto se mostre cogente verificar, tópicosistematicamente, a intensidade alcançada para, então sim, identificar a consubstanciação da espécie em tela.

Recorde-se, a calhar, que a ofensa à probidade administrativa encontra punição no diploma em comento de forma independente da ocorrência de dano material e da aprovação ou rejeição das contas pelos instrumentos de controles externo e interno. Decerto, presente o dano material ao erário sem 0 simultâneo enriquecimento ilícito, estar-se-á perante a segunda espécie de improbidade (prevista no art.10). De conseguinte, ao referir a penalidade de ressarcimento integral do "dano, se houver", no art. 12, III, novamente a dicção literal da lei não combina com a arquitetura normativa engendrada, salvo se se interpretar, com certo elastério, que o dano mencionado seria de natureza moral e reparável pela aplicação da multa. Independentemente desse argumento, vale recordar que a linguagem legal, embora arrevesada e vertida de forma incongruente, vale menos do que a imperativa visão finalística e atualizadora do sistema. Ora, numa leitura adequadamente sistemática e de cunho corretivo, capaz de imprimir a máxima efetividade ao princípio constitucional da probidade, resulta que o prescrito corre no sentido de que, para efetuar a reparação indenizatória dimanante da espécie elencada no art. 11, lançar-se-á mão do expediente da multa para punir tal improbidade, em sintonia implícita com o propósito constitucional. ${ }^{28}$ 
A reparação civil e política da quebra do princípio da moralidade tem a ver, ainda, com a independência do procedimento administrativo em face das esferas civil e penal. A despeito disso, com relação às decisões penais, há esteio legal para repercussão na seara administrativa (e.g., art. 126 da Lei n. 8.112/90), afastando-se a responsabilidade administrativa diante de absolvições criminais que neguem a existência do fato ou sua autoria. $\mathrm{Na}$ pendência, no entanto, nada autoriza sobrestar o procedimento administrativo. Ao versar sobre a perda da função pública, por provável desaviso, há quem sustente ter a Lei de Improbidade pretendido conferir garantias ínsitas à vitaliciedade ao estável ou - o que seria mais espantoso tecnicamente - até aos sequer possuidores de estabilidade. Contudo, a impositiva exegese sistemática do princípio da probidade solicita restringir o alcance do texto, a saber: quando, no art. 20, está dito que a perda da função pública somente se aperfeiçoa com o trânsito em julgado da sentença condenatória, o legislador, evidentemente, não veda (nem poderia) que, por intermédio de adequado processo administrativo disciplinar, imponha-se a perda da função daqueles que não são vitalícios. Seguramente, tal se apresenta a solução dotada de razoabilidade. Desse modo, para punir a improbidade que acarreta a pena demissória (no regime federal, art. 132 da Lei 8.112/90) não se mostra necessário suspender o procedimento administrativo. Tampouco nada impede o afastamento do agente público, mediante ato da autoridade competente, quando a medida se fizer indispensável à correta instrução.

Configurada a lesão ao patrimônio público por ação ou omissão, dolosa ou culposa, do agente e/ou de terceiro, dar-se-á o integral ressarcimento do dano, fazendo-os perder, no caso de enriquecimento ilícito, os bens ou valores acrescidos. Numa hipótese como noutra, cabe à autoridade administrativa responsável pelo inquérito representar ao Ministério Público para que este diligencie quanto à judicial indisponibilidade dos bens do indiciado, sem prejuízo do possível e mais aconselhável arresto - que a Lei impropriamente denominou de seqüestro - e, se for o caso, do bloqueio de contas bancárias e aplicações mantidas pelo indiciado no Exterior, se existir robusta verossimilhança quanto ao cometimento do ato merecedor de reprovação moral. Como é fácil perceber, não se trata de seqüestro, mas de arresto, apesar do equívoco nominal do legislador. Aliás, o próprio constituinte (CF, art. 100) valeu-se da expressão em sentido nominal indevido, além da recorrência do uso errôneo no plano infraconstitucional. Convém, no entanto, gizar que, embora ambos constituam medidas excepcionais de natureza cautelar, o seqüestro visa, com especificidade, a garantir a entrega de coisa determinada, ao passo que o inconfundível arresto - atendidos os seus requisitos inafastáveis e aplicando-se, tão-só, no que couber, os arts. 822 e 825 do CPC, para não desacatar o que reza $0 \S 1^{\circ}$, do art. 16 da Lei da Improbidade representa constrição dirigida a todo e qualquer valor ou bem capaz de assegurar o êxito da execução forçada por quantia certa, que é, afinal, a pertinente cogitando-se da presente ação civil.

Frise-se, ainda, que a ação principal haverá de ser intentada em trinta dias a contar da efetivação da medida cautelar, prosseguindo no rito ordinário. Não sendo ajuizada, mister recordar o caráter peremptório e decadencial de semelhante prazo, impondo-se que a medida cautelar seja extinta por ato de 
ofício do julgador, por se configurar situação típica de caducidade. Bem de ver, entretanto, que inocorre óbice para que outra ação civil de improbidade venha a ser proposta, nem mesmo para que a medida cautelar, em oportunidade futura, logre ser exitosa. Observe-se, além disso, aspecto de notável repercussão: o princípio constitucional da moralidade, mercê de sua autonomia, prossegue tutelável pela ação popular, pois qualquer cidadão pode impetrá-la para anular ato lesivo, por si só, à moralidade administrativa (CF, art. $5^{\circ}$, LXXIII), desde que produzida a prova da cidadania com a apresentação do título eleitoral ou com documento que a ele corresponda, facultando-se a terceiro habilitar-se como assistente ou litisconsorte. Diversamente, porém, do que ocorre na citada ação popular, a legitimação para a ação civil de combate à improbidade pertence apenas e, de modo privativo, ao Ministério Público ou à pessoa jurídica interessada. Quanto àquele, convém salientar que, se não atuar como parte, ao menos forçosamente haverá de fazê-lo custos legis nessa ação de improbidade, sob pena de nulidade, eis que se versa sobre interesses indisponíveis. No que tange à pessoa jurídica prejudicada, não parece razoável a invocação do princípio da economia processual para que a entidade venha ao processo com o intuito de defender o agente público, na suposta ânsia de preservar o ato de eventual anulação, visto que se trata de ação civil de objeto distinto, como remarcado, daquele que colima o anulamento do ato ilegal e lesivo.

Ainda no tocante à pessoa jurídica prejudicada, se esta não intentar a ação, atuará como litisconsorte facultativo, donde segue que o fato de, por exemplo, não ser citado um município prejudicado para integrar a lide não acarreta nulidade. Como é cediço, vislumbra-se possível, mas não obrigatória, a comunhão de interesses relativos à lide, cumprindo sublinhar que, em nosso sistema, o litisconsórcio somente se afigura necessário, no pólo ativo, quando a lei obrigar a demanda conjunta, o que não sucede na lei em apreço, dado que estampada a partícula disjuntiva no caput do art. 17. Não haveria racionalidade sequer remota em não reconhecer, no caso, ao Ministério Público a completa autonomia e independência para intentar e dar andamento à demanda, inclusive para, na defesa do interesse coletivo, pedir ressarcimento dos danos, independentemente da concordância da pessoa prejudicada. De outra parte, propondo o Ministério Público a ação principal, torna-se obrigatória, no cabível, a aplicação do par. $3^{\circ}$ do art. $6^{\circ}$ da Lei $4.717 / 65 .^{29}$

Mais: a ação terá de ser instruída com "indícios suficientes"30 de improbidade. $\mathrm{Na}$ ausência de tais elementos dotados de robustez e tendo o notificado introduzido as suas boas justificações, soa iníquo e atentatório à moralidade submeter, por mera insistência, alguém à "tortura" de um processo que pode destruir irremediavelmente a sua reputação e, em alguns casos, acarretar dano especial e anômalo, indenizável pelo Estado. Logo, com o devido comedimento, o juiz, acolhendo as explicações que evidenciem a insuficiência dos indícios, tem o dever ético-jurídico de rejeitar imediatamente a ação. Se não o fizer, está claro, em qualquer fase processual poderá extinguir o processo sem julgamento de mérito, ao se dar conta da inadequada e descabida ação de improbidade, por qualquer motivo. ${ }^{31}$ De fato, a compreensão serena de se estar diante de ação com violento e devastador impacto sancionatório aconselha filtragem severa da inicial, pois o processo 
não é substituto do inquérito nem serve para colmatar as suas lacunas ou eventuais inconsistências. O espírito da lei e, sobremaneira, do sistema administrativo, é o de punir o agente desonesto mediante graves e duras sanções civis e políticas, mas não aterrorizar, v.g., quem comete irregularidades desacompanhadas do timbre da desonestidade. ${ }^{32}$

Digno de menção, por derradeiro, que não parece a melhor linha interpretativa a de vedar acordo ou conciliação nas ações civis de improbidade administrativa (erro grave cometido pelo par. $1^{\circ}$ do art.17 da Lei 8.429/92), na contramão das melhores técnicas contemporâneas de valorização do consenso e da persuasão. O Direito Público do Século XXI, em novas bases, reclama estratégias conciliatórias que não significam dispor indevidamente do interesse público, mas, ao contrário, contribuem para afirmá-lo de modo mais efetivo. ${ }^{33}$ Impõe-se, desde logo, frisar que não se afigura universalizável a máxima que veda transação, acordo e a conciliação, notadamente essa última, que deve aflorar como uma estratégia preferencial na defesa do interesse público e da moralidade, jamais traduzível como qualquer condescendência abominável com os desonestos. Não há, pois, qualquer disponibilidade indevida do interesse público na conciliação em si.

\section{CONCLUSÕES}

Em face do articulado, emergem as seguintes principais conclusões:

(a) A ação civil e suspensiva do gozo de direitos políticos, prevista na Lei 8.429/92, consubstancia significativo e valioso mecanismo de resguardo do princípio superior e autônomo da moralidade pública. Com o advento da Constituição de 1988 e, secundariamente, de tal diploma, resultam superadas as antigas posturas que consideravam os juízos éticos como inteiramente desconectados ou estranhos à apreciação jurisdicional.

(b) A concretização da noção mestra da direito fundamental à boa administração pública supõe densificação sensata do princípio constitucional da probidade administrativa, superadas as apontadas falhas da Lei 8.429/92. Faz-se, pois, imperativo examinar referido diploma legal com a necessária cautela, de maneira que, em casos menos graves, ocorra a aplicação tão-só parcial das sanções ali previstas, designadamente para as espécies de improbidade dos arts. 10 e 11. Claro que a melhor exegese - a mais eficaz e justa - do disposto no art. 12, é a que determina ao juiz considerar a extensão do dano causado e o proveito patrimonial obtido pelo agente, inclusive na eleição das penalidades, não apenas na dosimetria. Desvestida, assim, a Lei da Improbidade de suas feições originárias algo abusivas, está pronta para ser manejada pelos legitimados ativos, evitando-se o desgaste de subsunção infrutífera e comprometedora da proporcionalidade. Em outras palavras, é no papel concretizador do princípio da probidade, mais do que na exterioridade das regras, na fundamentação dos atos administrativos, que devem ser concentradas as mais altas forças do revigoramento dos vínculos éticos no âmbito das relações jurídico-administrativas. 
(c) Orientou-se o legislador pátrio para dimensão eminentemente repressora à desonestidade para com a coisa pública. Entretanto, sem que se receba tal obra com olhos reducionistas e acríticos, bem de ver como irrefutável que soluções de fundo hão de ser diligenciadas em paralelo, e residem tendencialmente na transformação educativa e persuasiva (pedagógica até) da sociedade, tarefa que será tanto mais veloz quanto melhor se interpretarem e aplicarem os diplomas em prol da efetivação incisiva do princípio jurídico da moralidade. Seguramente, a exegese finalística e moderada, nos termos propostos, não dispensa alterações legislativas, tampouco as de matriz sociológica, nem substitui, muito ao contrário, o trabalho de sensibilização formativa do agente público e da própria coletividade.

(d) Faz-se imprescindível, bem menos por temor e muito mais por sadia persuasão, interiorizar padrões ético-jurídicos superiores se se quiser timbrar a jornada democrática dos que lidam com a coisa pública com o acatamento cabal dos princípios regentes das relações de administração. De fato, o agente público deve tratar, com seriedade e diligência, o leal cumprimento dos seus deveres. Indubitavelmente, a moralidade apenas será universalizada, gerando o afastamento do improbus administrator e dos seus comparsas, se vivificada sem ingenuidade ou demasiado ceticismo niilista - a noção de cidadania altiva e adulta. Apenas desse modo, o Estado-Administração, em suas múltiplas facetas, reunirá forças necessárias para atuar com previsibilidade e segurança, numa concretização proba, transparente, eficaz e efetiva dos princípios constitucionais, relidos e vivenciados em dimensão moral superior.

\section{REFLECTIONS ON MORALITY AND ADMINISTRATIVE LAW}

\section{ABSTRACT}

The constitutional principle of morality suggests a new and deeper control of administrative acts, and allows a more effective assimilation of the fundamental right to good public administration. Moralism is the risk to be avoided, i.e., the hypertrophy of this principle to the detriment of the other ones. Thus, in this article, an adequate, moderate and proportional approach will be defended.

Keywords: Administrative acts. Constitutional principle. Morality. Public administration.

\section{NOTAS}

Prof. Titular do Mestrado e Doutorado em Direito da PUCRS, Prof. de Direito Administrativo da Universidade Federal do Rio Grande do Sul, Presidente do Instituto Brasileiro de Altos Estudos em Direito Público e do IDARGS, Membro do Conselho Nato do Conselho do Instituto Brasileiro de Direito Administrativo. É Membro da Comissão Especial sobre Direito da Regulação do Conselho Federal da OAB, Pós-Doutorado em Direito na Universidade Estatal de Milão, Advogado, Parecerista. 
1 Vide meu livro Discricionariedade Administrativa e o Direito Fundamental à Boa Administração Pública. São Paulo: Malheiros, 2007, p. 20.

2 In: Elogio da Serenidade. São Paulo: Unesp, 2002, p.98. Assinala: "Para poder viver e reforçar-se, uma democracia necessita da máxima extensão da relação de confiança recíproca entre os cidadãos, e portanto da eliminação, tão completa quanto possível, da estratégia da simulação e do engano (o que quer dizer também a redução, tão grande quanto possível, do espaço do segredo". Adiante, propõe uma "educação universalista" (p. 130), ponderando: "Concepções éticas universalistas são aquelas que têm como meta última da história, ainda que ideal, a formação da civitas maxima, a cidade de todos, e tendem a fazer de todo homem um cidadão do mundo [...]" (p.131)

3 In: The Authority of Law: Essays on Law and Morality. Oxford: Clarendon, 1979, p. 47.

4 Bem verdade que o "soft positivism", por exemplo, de Herbert Hart, reconhece que "the rule of recognition may incorporate as criteria of legal validity conformity with moral principles or substantive values" in The Concept of Law. Oxford: Clarendon Press, 1994, p. 250. Em contraposição, acerca da vinculação entre Direito e Moral, vide, entre outros, Ronald Dworkin in Freedom's Law, The Moral Reading of the American Constitution. Cambridge: Harvard University Press, 1996.

5 Em que pese não se ignorar a notável contribuição de Quine ao problematizar a fronteira entre analíticos e sintéticos in From a Logical Point of View. Cambridge: Harvard, 1953.

6 In: Direito e Democracia: entre faticidade e validade, vol. II, Rio de Janeiro: Tempo Brasileiro, 1997. Observa: "O direito constitucional revela que muitos desses princípios possuem uma dupla natureza: moral e jurídica. Os princípios morais do direito natural transformaram-se em Direito positivo nos modernos Estados constitucionais" (p. 203). Não é pouco agasalhar semelhante idéia de que a legitimidade da legalidade resulta do entrelaçamento entre o jurídico e uma argumentação moral. O que se mostra relevante é grifar que inexiste Direito que não deva ser "limitado a partir de considerações de princípio", algo que Habermas enfatiza ao examinar as decisões de controle abstrato do Tribunal Constitucional Federal alemão. Importa, igualmente, destacar o seu acerto de rumo, quando, diferentemente de Weber, entende que o Direito não pode mais ser construído como possuindo uma racionalidade isenta da moral e, a rigor, jamais se deixou erguer deste modo. Observa: "Um poder exercido nas formas do direito positivo deve a sua legitimidade a um conteúdo moral implícito nas qualidades formais do Direito" (p.214).

7 Sobre o tema, vide Rogério Gesta Leal in O Estado-Juiz na Democracia Contemporânea. Uma perspectiva procedimentalista. Porto Alegre: Livraria do Advogado, 2007.

8 Vide, a propósito, Robert Alexy in Begriff und Geltung des Rechts. München: Verlag Karl Alber Freiburg, 1992, pp. 15-17. Para enfrentar a questão decisiva de saber como é possível a legitimidade por intermédio da legalidade importa indagar, no fundo, acerca da vinculação entre Direito e Moral. Alexy divide os juristas entre os que afirmam e os que negam tal vinculação. Alinha-se, está claro, entre os que aceitam e proclamam o liame, isto é, a mútua influência entre o jurídico e o moral. De sua vez, Jürgen Habermas, in ob. cit., sustenta a idéia de que a "legalidade tem que extrair sua legitimidade de uma racionalidade procedimental com teor moral" (p. 194). Ora, em alguns casos, a própria Administração Pública deve fazer uma espécie de controle de moralidade. Nesse quadro, bem de ver que, entre os demais princípios cogentes, avulta o princípio da moralidade além de uma simples derivação do princípio do devido processo legal. Em tal contexto, tem razão ao criticar o formalismo supostamente racional do Direito. Diversamente do sustentado por Weber, nesse ponto, percebe-se que, sem essa materialização ou visão substancialista do Direito em sua interpretação, faz-se impossível compreender as características do sistema jurídico contemporâneo. Em que pese a importância do princípio da segurança jurídica, as qualidades formais do Direito apontadas por Weber mostram-se decididamente incapazes, como notou Habermas, para dar conta da "eficácia legitimadora" da legalidade. Para além de falácias formalistas, mister notar que a racionalidade jurídica tem mais a ver com a razão prática, em lugar da racionalidade científica no sentido de outrora. Desta maneira, andou bem ao asseverar que os limites entre o Direito e a Moral não podem ser estabelecidos unicamente com os conceitos 'formal' e 'material'. Dito de outro modo: a legitimidade da legalidade resulta mesmo de uma "relação interna entre o Direito e a Moral". Já no exame da legitimidade da produção do Direito, sobretudo ao se constatar a dicotomia entre normas primárias e secundárias (Hart), torna-se imprescindível investigar os discursos jurídicos no espaço que transcende a "completude." Como percebeu Habermas: "O direito constitucional revela que muitos desses princípios 
possuem uma dupla natureza: moral e jurídica. Os princípios morais do direito natural transformaram-se em Direito positivo nos modernos Estados constitucionais" (p. 203), donde segue a inafastável permeabilidade ou porosidade do jurídico em face de argumentações eminentemente morais. Indo, entretanto, além de Habermas, neste passo, observa-se que a dupla natureza apontada não diz respeito a vários, mas a todos os princípios jurídicos, sem exceção. Mostra-se relevante grifar que inexiste Direito que não deva ser "limitado a partir de considerações de princípio", algo que Habermas enfatiza ao examinar as decisões de controle abstrato do Tribunal Constitucional Federal alemão. Importa, em suma, destacar o seu acerto quando, diferentemente de Weber, entende que o Direito não pode mais ser construído como possuidor de uma racionalidade isenta da moral e, a rigor, jamais se deixou erguer deste modo. Assinala: "Um poder exercido nas formas do direito positivo deve a sua legitimidade a um conteúdo moral implícito nas qualidades formais do Direito" (p.214). Como afirmado, não há espaço para julgar aqui as teorias procedimentalistas da justiça de Rawls, Kohlberg ou Apel, além da do próprio Habermas, vendo a argumentação moral como processo adequado para a formação racional da vontade e da busca cooperativa da verdade, admitindo tão-só a coerção do melhor argumento. Por igual, não cabe adentrar no exame do conceito restrito de moral, ao qual, na ótica de Habermas, deveria corresponder uma modesta autocompreensão da teoria da moral. Impende somente destacar, por enquanto, que o Direito reclama uma fundamentação também moral. Sobre o tema, vide Alessandro Pinzani in "Problemi di Applicazione nella Teoria Discorsiva della Morale e del Diritto." Ermeneutica e Applicazione, Annuario di ermeneutica giuridica, Padova: CEDAM, 1996, pp. 55-71.

9 Sobre o tema do controle, vide a excelente obra de Germana de Oliveira Moraes in Controle Jurisdicional da Administração Pública. São Paulo: Dialética, 1999.

10 Vide, a propósito, Cass Sunstein in The Partial Constitution, Cambridge: Harvard University Press, 1993, em sua defesa da "república das razões" e da imparcialidade.

11 Vide Edgar Morin in Saberes Globais e Sabers Locais. Rio: Garamond, 2008, p; 30: "O desenvolvimento da ciência também esteve intimamente ligado à quantificação.O que não pudesse ser quantificado estava eliminado do conhecimento, não existia.Entretanto, a existência não pode ser quantificada". Correto, mas isso não significa abrir mão dos controles mensuráveis, aqui defendidos, mas de, sistematicamente, ir além.

12 Nos termos examinados, em profundidade, em meu livro A Interpretação Sistemática do Direito. São Paulo: Malheiros, 4. ed., 2004. Vide, também, o meu livro Discricionariedade Administrativa e o Direito Fundamental à Boa Administração Pública. São Paulo: Malheiros, 2007.

13 Vide Riccardo Guastini in Distinguiendo. Barcelona, Gedisa, 1999, p. 166, ao destacar o papel dos princípios na justicação externa das premissas.

14 Vide, para cotejo, a lei moral, presente no art. $2^{\circ}$ da Carta Alemã.

15 Dito em outro ângulo, fazendo "do sistema dos direitos fundamentais o critério último de validade de toda ordem jurídica", no dizer Cristina Queiroz in Interpretação Constitucional e Poder Judicial. Coimbra: Coimbra Editora, 2000, p. 332.

16 Sobre a inadmissibilidade da responsabilidade objetiva do agente em ação de improbidade administrativa, vide Resp 802382/MG, Rel. Min. Denise Arruda.

17 Apenas para ilustrar, sobre o tema, na literatura nacional, mencionem-se: Márcio Cammarosano in Princípio constitucional da moralidade e o exercício da função administrativa. Belo Horizonte: Forum, 2006. Juarez Freitas in "Do princípio da probidade administrativa e de sua máxima efetivação". Revista de Direito Administrativo, v. 204, pp. 65-84. Marcelo Figueiredo in Improbidade administrativa. 5.. ed. São Paulo: Malheiros, 2004. Improbidade administrativa: questões polêmicas e atuais (Bueno, Cássio Scarpinella; Porto Filho, Pedro Paulo de, Coords.), São Paulo: Malheiros, 2001. Rogério Pacheco Alves; Emerson Garcia in Improbidade administrativa. Rio de Janeiro: Lúmen Júris, 2002. Cláudio Ari Mello in "Improbidade administrativa: considerações sobre a Lei ํo 8.429/92". Fábio Medina Osório in Improbidade administrativa. Porto Alegre: Síntese, 1998. Germana de Oliveira Moraes in Controle jurisdicional da administração pública. São Paulo: Dialética, 1999. Diogo de Figueiredo Moreira Neto in "Moralidade administrativa: do conceito à efetivação". Revista de Direito Administrativo, Rio de Janeiro, n. 190, p. 1-44, out./dez. 1992. Cármen Lúcia Antunes Rocha in "Improbidade administrativa e controle das finanças públicas". Revista do Tribunal de Contas de Minas Gerais, n. 4, v. 37, pp. 101-125.

18 Vide Celso Bandeira de Mello in "Competência para julgamento de Agentes Políticos por ofensa à lei de Improbidade Administrativa."Revista Interesse Público n. 42, pp 15-19. 
19 Não parece se coadunar com o espírito da Constituição a exigência de "mais da metade do patrimônio ou da receita anual", presente no art. $1^{\circ}$ da Lei 8.429/92.

20 Art. $1^{\circ}$, parágrafo único. Estão também sujeitos às penalidades desta lei os atos de improbidade praticados contra o patrimônio de entidade que receba subvenção, benefício ou incentivo, fiscal ou creditício, de órgão público bem como daquelas para cuja criação ou custeio o erário haja concorrido ou concorra com menos de cinqüenta por cento do patrimônio ou da receita anual, limitando-se, nestes casos, a sanção patrimonial à repercussão do ilícito sobre a contribuição dos cofres públicos.

21 Vide, entre outros, os seguintes precedentes do STF acerca da independência de instâncias: MS 21.294-DF, MS 21.293-DF, MMSS 21.545-SP, 21.113-SP e 21.321-DF, MMSS 21.294-DF e 22.477-AL.

22 Vide Recurso Especial 324282.

23 Para ilustrar, no campo jurisprudencial, vide o julgamento da AC 70004123519, pelo TJRS, em cuja ementa se lê: "Prejuízo ao erário. Ação procedente. Responsabilidade caracterizada. Observância, porém, do princípio da proporcionalidade em relação à extensão do dano. Abrandamento dos rigores da lei (art.12, parágrafo único, da Lei 8.429/92), afastando a aplicação cumulativa das penas acessórias e de multa. Moderação punitiva, restrita à sanção pecuniária, a título de indenização. Recurso parcialmente provido" Vide, ainda, o julgamento da AC no 597156983. em 30/06/1999, no TJRS, em cuja ementa se lê: "1. O prejuízo do erário deve ser efetivo e restar provado, e não presumido. 2. O julgador, ao aplicar aos agentes da administração pública as pesadas penas da Lei n. 8429, de 2.6.1992, deve ter em mente o principio da proporcionalidade, para não cometer injustiça, mormente quando não houve prejuízo algum ao erário e resquício sequer de enriquecimento ilícito de parte dos agentes políticos demandados e das empresas licitantes. 3. A jurisprudência tem-se orientado no sentido de exigir, em ações populares, a comprovação efetiva do dano, e, estando ausente a lesividade ao erário, e a obra ou serviço concluídos e realizados, a tendência é de considerar improcedentes ações populares promovidas sob o argumento de violação à moralidade administrativa, sobretudo quando presentes vícios formais.4. Sem lesividade ao erário, não haverá enriquecimento ilícito de parte do agente da administração pública, pois a lesividade é causa do enriquecimento ilícito, e este, conseqüência daquele. 5. Apelo provido em parte, por maioria."

24 A propósito, vide AC 246206 do TRF da $5^{\text {a }}$ Região , em cuja ementa se lê: "- Para a configuração de qualquer dos tipos previstos nos incisos do art. 10 da referida lei, é imprescindível que o agente tenha causado efetiva lesão aos cofres públicos, ensejando perda patrimonial, desvio, apropriação, malbaratamento ou dilapidação dos bens e haveres das entidades da administração direta, indireta ou fundacional, de qualquer dos poderes da união, estado, distrito federal, municipal ou território. - Não se pode reduzir ou circunscrever-se a improbidade administrativa à hipótese de simples infração ao princípio da legalidade, conforme se depreende do texto do art. 11. A eventual ilegalidade, cometida pelo administrador, somente configurará improbidade administrativa quando sua conduta tentar efetivamente contra padrões da moralidade administrativa.- Apelação improvida."

25 Vide Resp 831178/MG, em cuja ementa se lê: "a exegese das regras insertas no art. 11 da Lei 8.429/92,considerada a gravidade das sanções e restrições impostas ao agente público, deve ser realizada cum granu salis, máxime porque uma interpretação ampliativa poderá acoimar de ímprobas condutas meramente irregulares, suscetíveis de correção administrativa, posto ausente a má-fé do administrador público, preservada a moralidade administrativa e, a fortiori, ir além de que o legislador pretendeu. 3. A má-fé, consoante cediço, é premissa do ato ilegal e ímprobo e a ilegalidade só adquire o status de improbidade quando a conduta antijurídica fere os princípios constitucionais da Administração Pública coadjuvados pela má-intenção do administrador."

26 Vide REsp 324730/SP.

27 Sobre a exigência de intenção manifesta de violar a moralidade, vide, por exemplo, REO 185968, julgado pelo TRF-5a Região. "1. De acordo com a Lei n. 8.429/92 consiste em improbidade administrativa a omissão ou o retardamento da prática de ato de ofício. 2 . Apesar de tal circunstância ser definida como atentatória aos princípios da administração pública, a aplicação do comando legal não pode prescindir de ponderações acerca do princípio da razoabilidade. 3 . Não tendo sido caracterizada a intenção manifesta de mitigar a moralidade administrativa, o que afasta a presença do dolo na conduta do agente 
político, injustificável o enquadramento da questão como improbidade. 4. O envio das comunicações exigidas consoante 0 art. $2^{\circ}$ da Lei $n . .9452 / 97$, acerca da liberação de verbas federais em favor da edilidade, mesmo que extemporaneamente, não implica, por si só, a falta de transparência na gestão da coisa pública. 5. Remessa oficial improvida."

Em sentido correlato, poder-se-ia corroborar a assertiva invocando o art. 1으 da Lei da Ação Civil Pública, com a redação dada pela Lei 8.884/94, ao admitir, sem prejuízo da ação popular, o cabimento de ações de responsabilidade por danos morais - além dos patrimoniais -, causados ao consumidor, neste caso interessando, na analogia, o tangente a serviços remunerados à base de preços públicos.

O par. $3^{\circ}$ do art. 17 da Lei 8.429/92 foi alterado pela Lei 9.366/96. Vide Medida Provisória 2.225/2001, especialmente ao alterar o parágrafo $6^{\circ}$ do art. 17 da Lei 8.429/92.

31 Vide MC 2940.

32 Vide, a propósito, o julgamento do Recurso Extraordinário 160432/SP, em cuja ementa se lê: "A rejeição legislativa de contas públicas, com fundamento na ausência de aplicação do percentual compulsório mínimo determinado pelo texto constitucional em favor do ensino fundamental, não conduz, por si só, ao reconheciment de uma situação caracterizadora de improbidade administrativa".

33 Por ora, entre tantos, vide, e.g., Philip Harter in Negotiating Regulations: A Cure for Malaise, 71 Geo. L.J (1982).

\section{REFERÊNCIAS}

ALEXY, Robert. Begriff und Geltung des Rechts. München: Verlag Karl Alber Freiburg, 1992.

BOBBIO, Norberto. Elogio da Serenidade. São Paulo: Unesp, 2002.

CAMMROSANO, Márcio. Princípio constitucional da moralidade e o exercício da função administrativa. Belo Horizonte: Forum, 2006.

DWORKIN, Ronald. Freedom's Law, The Moral Reading of the American Constitution. Cambridge: Harvard University Press, 1996.

FREITAS, Juarez. A Interpretação Sistemática do Direito. São Paulo: Malheiros, 4. ed., 2004.

. Discricionariedade Administrativa e o Direito Fundamental à Boa Administração Pública. São Paulo: Malheiros, 2007.

Do princípio da probidade administrativa e de sua máxima efetivação. Revista de Direito Administrativo, v. 204, pp. 65-84.

GUASTINI, Ricardo. Distinguiendo. Barcelona: Gedisa, 1999.

HABERMAS, Jürgen. Direito e Democracia: entre faticidade e validade. vol. II Rio de Janeiro: Tempo Brasileiro, 1997.

HART, Herbert. The Concept of Law. Oxford: Clarendon Press, 1994. Em contraposição,

LEAL, Rogério Gesta. O Estado-Juiz na Democracia Contemporânea. Uma perspectiva procedimentalista. Porto Alegre: Livraria do Advogado, 2007.

MORAES, Germana de Oliveira. Controle Jurisdicional da Administração Pública. São Paulo: Dialética, 1999. 
MORIN, Edgar. Saberes Globais e Saberes Locais. Rio de Janeiro: Garamond, 2008.

PINZANI, Alessandro. Problemi di Applicazione nella Teoria Discorsiva della Morale e del Diritto." Ermeneutica e Applicazione, Annuario di ermeneutica giuridica, Padova: CEDAM, 1996, pp. 55-71.

QUEIROZ, Cristina. Interpretação Constitucional e Poder Judicial. Coimbra: Coimbra Editora, 2000.

RAZ, Joseph. The Authority of Law: Essays on Law and Morality. Oxford: Clarendon, 1979.

SUNSTEIN, Cass. The Partial Constitution. Cambridge: Harvard University Press, 1993.

Recebido para publicação 02/12/2008

Aceito para publicação 19/12/2008 